\title{
Becoming a Citizen: Marriage, Immigration, and Assimillation
}

\author{
Kerry Abrams
}

\section{Introduction}

Most U.S. citizens are born that way. But for immigrants, becoming a citizen is a slow process. This process includes applying for a "green card," which gives an immigrant the right to reside legally in the United States. A limited number of green cards are available, and applicants must demonstrate that they qualify for a green card, most commonly by showing a family relationship to a U.S. citizen or employment with a U.S. company. Obtaining a green card can take many years, and once an immigrant has obtained one, she must reside in the United States for several more years before she can apply to become a naturalized citizen, which in turn requires a civics test, an English language test, demonstration of good moral character, and an oath of loyalty to the United States. Becoming a citizen is not a one-time event that occurs when an immigrant takes the loyalty oath, but a slow process of demonstrating value to the nation and assimilation to its culture and values.

This chapter examines how this experience of becoming a citizen is affected by, and in turn further entrenches, gender inequality. Although the law of immigration and naturalization comports with principles of formal gender equality, the law, especially the law of immigration, has gendered effects. Women are eligible to apply for green cards based on a variety of qualifications, and their ability to qualify is determined primary by the economic and cultural circumstances from which they come. Most women are unable to meet the qualifications required for a green card based on employment because they lack the skills deemed important by the United States. Instead, the vast majority of women who apply to become permanent residents do so based on relationships with U.S. citizen family members, usually husbands. The result is that the pool of people available to seek naturalized citizenship includes a disproportionate number of women who are eligible because of their marital relationship and a disproportionate number of men who are eligible because of their occupational skills.

Because marriage itself is a gender-producing institution, a system that creates future citizens based on marital status has profound effects for the way in which men and women experience becoming American. For both men and women who 
seek citizenship through marriage, it is heterosexual marriage itself, and not the loyalty oath or civics test, that provides the most important vehicle for assimilation. Although marriage, and immigration law's use of marriage, have changed dramatically over the past hundred years, immigration law still makes the assumption that heterosexual marriages include a breadwinner, with decision-making authority over issues such as residency, and a subordinate spouse (a "derivative spouse" in immigration law terms), who is dependent financially on the breadwinning spouse. It requires couples to demonstrate their conformity with these norms, even in cases where the norms simply do not fit. And in cases where the norms do fit, the requirement of conformity further entrenches the notion that these norms represent what is expected of American families.

One of the legal mechanisms for imposing this dichotomous and gendered view of marriage is the discretion it gives a citizen to decide whether or not to sponsor his immigrant spouse for a green card. Because this broad discretion is often abused by spouses who are batterers, Congress has created numerous exceptions to the normal rules for immigrants who can prove they have been battered. The creation of this class of future citizens further genders the pool of immigrants eligible for naturalization: many future U.S. citizens are eligible because they are battered spouses; they must show victimhood to demonstrate their worth as citizens. The remainder of this chapter examines in more detail how immigration law produces future citizens and the relationship between this process and the production of gender.

\section{Immigration as the Gatekeeper of Citizenship}

Citizenship, like all status categories, serves a gatekeeping function. By demarcating who is in and who is out, it defines the collective whole. 'Those who are in are, in the famous words of T. H. Marshall, given the "basic human equality associated with ... full membership of a community." Most citizens in the United States today are citizens by birth: their experience of citizenship is essentially ascriptive. In contrast, citizens who naturalize make a choice to be governed by the United States, and the United States makes a choice to accept them as citizens. In the United States, the criteria the government uses in making the decision to accept an immigrant as a naturalized citizen include a civics test, an English test, demonstration of good moral character, residency for a number of years, and an oath of loyalty to the United States. Much has been written about what these criteria say about American self-definition and the meaning of American citizenship. ${ }^{3}$

1 See Rogers Brubaker, Citizenship and Nationhood in France and Germany (Cambridge, MA: Harvard University Press, 1992), at 23-31.

2 T. H. Marshall, Citizenship and Social Class and Other Chapters (Cambridge: Cambridge University Press, 1950), at 8.

3 See, e.g., Gerald Neuman, “Justifying U.S. Naturalization Policies," 35 Va. J Int'l L.. 237, 267 (1994); Peter J. Spiro, "Questioning Barriers to Naturalization," 13 Geo. Immigr. L. J. 479 (1999). 
But naturalization law does not tell the entire citizenship story. The naturalization oath takes only a minute to recite, but the demonstration of worth required to become a citizen begins the minute an immigrant applies for legal residency. Simone de Beauvoir famously stated that "one is not born, rather, one becomes a woman." Similarly, immigrants who become naturalized citizens of the United States obtain their citizenship status not through an accident of birth, but instead, by repeatedly demonstrating their worth in ways that shape their identity and encourage assimilation to American culture. For naturalizing citizens, the oath is a rite of passage, the institution of a new relationship between individual and nation. But the citizenship oath itself is merely the last in a lengthy series of acts that the immigrant must undertake to demonstrate his or her value to the country.

To become a naturalized citizen, an immigrant must first become a lawful permanent resident (commonly referred to as a "green-card holder"). Green cards are not available to everyone one who wants one. Instead, U.S. immigration law sets out specific categories of immigrants who can qualify for permanent residency, and even those who qualify may sometimes have to wait many years before obtaining lawful residency because most categories are subject to annual quotas. Eligible immigrants include family members of U.S. citizens or permanent residents, immigrants who are sponsored by a U.S. employer for a particular job, political refugees, and socalled diversity immigrants from underrepresented countries who enter a lottery for U.S. residency. Of these categories, family-based immigrants receive by far the most generous quotas and therefore dominate the number of immigrants who receive a green card each year. For example, in 2007 , over 1 million immigrants were granted green cards, and of these, approximately 65 percent received them based on a family relationship to a U.S. citizen or resident, while around 15 percent went to immigrants sponsored by an employer and nearly 8 percent went to refugees or asylees fleeing persecution in their home countries. ${ }^{4}$ Family relationships, with a strong emphasis on nuclear family relationships, predominate in shaping the pool of people eligible to obtain naturalized citizenship.

Once an immigrant demonstrates that she fits within one of the prescribed categories, she must also demonstrate what she is not: a terrorist, an addict, a prostitute, a polygamist, or a child abductor. Even people who otherwise satisfy the admissions criteria will be excluded if they fall into any of these categories. So, too, will a person with a criminal record, if the crime involved "moral turpitude" or if more than one crime was committed; anyone who enters illegally or with false documents (even if the correct documents would demonstrate that the person fits one of the admission categories); or a person with a communicable disease. There are very few ways around these exclusions; for most of them, the only way to obtain discretionary relief is by demonstrating "extreme hardship" to a U.S. citizen or permanent

4 "Yearbook of Immigration Statistics: 2007," Table 6, U.S. Department of Homeland Security, available at http://www.dhs.gov/ (accessed Oct. 30, 2008). The percentages do not total 100 because there are other categories such as diversity immigrants. 
resident family member. ${ }^{5}$ Thus, these requirements function to limit further the pool of potential citizens, once again by privileging those with family ties over others.

After an immigrant has obtained green card status, the clock begins ticking until the date when she is eligible to apply to become a naturalized citizen. A would-be citizen must reside continuously within the United States for at least five years. In addition, to naturalize, an immigrant must demonstrate sufficient seriousness and assimilation to American values, language, and culture by carrying on a conversation in English, passing a civics test, swearing allegiance to the United States, and demonstrating "good moral character." But never again must the naturalizing immigrant demonstrate that she qualifies for admission by virtue of a family tie, employment, persecution, or luck. Those gatekeeping questions were already asked and answered through the immigration process and now appear to be irrelevant for purposes of naturalization. The immigration restrictions, however, belie the idea that citizenship is merely a question of loyalty and assimilation. Only those immigrants who initially qualified for permanent residence will be qualified to apply for citizenship. Immigration laws, even though they are not formally considered to be rules of naturalization, thus regulate membership by acting as gatekeepers of who can be admitted to the pool of eligible applicants for naturalized citizenship. Accordingly, immigration law performs much of the gatekeeping function usually attributed to naturalization in citizenship theory.

This function is easy to overlook, in part because the law has neatly divided citizenship and immigration into two separate areas, with citizenship law treated as constitutional and important to national identity and immigration law as technical and statutory. Citizenship is clearly constitutional: all persons born in the United States and subject to the jurisdiction thereof are, under the language of the Fourteenth Amendment, U.S. citizens, and the U.S. Constitution gives Congress the power to create a "uniform rule of naturalization." But the power to regulate immigration is constitutional as well: although no particular clause grants Congress this power, the Supreme Court has repeatedly held that the federal government enjoys "plenary power" over immigration for a variety of reasons, including the country's status as a sovereign nation entitled to protect its borders. ${ }^{7}$

The law governing citizenship takes its cue from the naturalization clause and focuses on a uniform rule. But there is nothing in the Constitution requiring that immigration law be uniform, and, indeed, it is not. The United States frequently makes distinctions between incoming immigrants based on national origin, marital status, or educational background in the context of deciding who qualifies for a green card and offers immigration officials significant discretion in determining whom to admit. The law of immigration focuses not on uniformity, but on diversity: how to

\footnotetext{
5 See 8 U.S.C. SS 1182 (a), (g), (i) (2008).

68 U.S.C. SS 1427 (a)-(b) (2006).

7 U.S. Constitution, Amendment XIV; U.S. Constitution, Article I, \$ 8, cl. 4; Fiallo v. Bell, 430 U.S. 787 (1977) (articulating plenary power doctrine); Kleindienst v. Mandel, 408 U.S. 753 (1972) (same).
} 
choose from a variety of possible future citizens the ones who will become eligible to qualify under the uniform rule.

Citizenship, as this book demonstrates, has many meanings. It can refer to the possession of political, civil, and social rights; active engagement in the life of the political community; and ties of identification and solidarity. Many people who are not technically citizens enjoy some of these features of what we call "citizenship": they may, for example, be actively engaged in their communities, feel solidarity with the United States, and intend to live here permanently (a green card holder is, after all, a "permanent resident"). But becoming a naturalized citizen gives an immigrant full political rights, including the right to remain in the country even if she commits a crime, the right to return if she leaves the country's borders, and the right to vote in federal elections. Citizenship status is durable: it cannot be taken away unless the citizen expresses a clear intent to expatriate herself, and under many circumstances, U.S. citizens can transmit their American citizenship to their children even if their children are born abroad, thus creating a new generation of American citizens. A green card holder is a permanent resident, but only a partial member; it is only upon naturalization that an immigrant becomes a full-fledged member of the political community.

Understanding how immigrants become citizens, then, requires an understanding of the entire process of becoming, not just the moment of naturalization. It is through the entire naturalization process that the United States most clearly articulates what it requires of its citizens. Unlike citizens by birth, naturalized citizens are in a position to consent as adults to be governed and to take part in the governing that democracy entails. The questions the country asks of naturalizing citizens and how naturalizing citizens experience their becoming American are therefore crucial to understanding what American citizenship means.

Neither the uniform rule of naturalization nor the law of immigration appears to be gendered. Nowhere does the Immigration and Nationality Act distinguish, for example, between husbands and wives of U.S. citizens, between brothers and sisters, or between male employees of U.S. companies and female employees. Yet immigration law is profoundly gendered in the way that it shapes the pool of immigrants available to become naturalized citizens because it uses the family as a preselection device in deciding which immigrants are worthy of gaining legal resident status and because it privileges some employment skills over others. ${ }^{8}$ Given the gendered

8 In this chapter, I focus solely on the process of becoming a naturalized citizen. There are certainly things to say about the gendered aspects of citizenship by birth. Many commentators have pointed out the highly gendered nature of the jus sanguinis (citizenship by blood) doctrine, as shown in Nguyen $v$. INS, 533 U.S. 53 (2001), a case in which the U.S. Supreme Court upheld a statute that gives automatic citizenship to children born abroad to female U.S. citizens but requires children born abroad to male U.S. citizens to demonstrate their fathers' intent to parent, through either marriage to the mother or other acts demonstrating intent to claim paternity before the child turns eighteen. Although it is true that this case shows a stark disparity in how the law conceives of male and female citizens and their ability to transmit citizenship to their children based on biological and social gender roles, as Rogers Smith argues in Chapter 1 of this volume, the number of people affected by the Nguyen holding 
family systems and employment markets that exist in immigrants' home countries, it should be no surprise that their ability to obtain legal residency is also influenced by gender.

\section{Becoming a Citizen Through Employment}

One path to citizenship for immigrants is employment-based permanent residency. To obtain a green card under most employment preference categories, an immigrant must have a job offer from an American company that has demonstrated its inability to find an American worker to do the job. The employee is, at least theoretically, filling a gap in the American work force and contributing to the efficiency of the U.S. economy. The most preferred category goes to "priority workers," which include aliens with "extraordinary ability" who have obtained "sustained national or international acclaim" for their work; "outstanding professors or researchers;" and "multinational executives and managers." The second category includes "professionals holding advanced degrees" and immigrants with "exceptional ability in arts, sciences, or business." The third category includes "skilled workers in short supply," "professionals with baccalaureate degrees," and "unskilled workers." Each of the first three categories has an annual quota of 40,000 workers, but the third category has a special subquota for so-called unskilled workers of just 10,000. There is also a fourth category for "special immigrants," which include clergy and former government employees, with a quota of 10,000 , and a fifth category for "investors" who plan to hire Americans and invest at least $\$ 1$ million in a business venture.? Together, these categories work to generate a large pool of highly skilled workers and keep the number of unskilled workers low.

As one might suspect from examining the employment-based immigration options, most people who enter the United States to work cannot achieve permanent residency. They either use temporary work visas that expire after a certain amount of time, or they enter illegally. Employment-based permanent residence visas (those that confer a green card) are limited by Congress to a maximum of 140,000 per year. The supply of these visas is far less than the demand, whether demand is measured by the immigrants who would like permanent residence and work in the United States or by the employers who would like to hire them. The government limits the number of employment visas because of the broad rights they confer. As a green card holder, an immigrant can quit her job and take another, or not work at all; she is not a temporary worker or guest, but a potentially permanent part of the work force, with the personal autonomy that a U.S. citizen worker would have. In five years, she will be eligible to naturalize even if she quit her job immediately after

is relatively small. I deal here with an issue that affects more people and has greater consequences for the expressive power of law: the requirements that citizenship law and immigration law place on immigrants who desire to naturalize and the gendered consequences of these requirements.

98 U.S.C. $\int 1153$ (b) (2006). 
arrival. Granting an immigrant permanent resident status based on a particular job offered by a particular employer is a risk for the country, and it is a risk the country is willing to take only in cases where the immigrant has skills that are relatively scarce and likely to produce employment regardless of the solvency or status of a particular employer. The result is that the majority of slots for employment-based immigration go to immigrants with high levels of education or practice-based skills.

It should be no surprise that a system that values education and skills that require sustained employment would lead to unequal outcomes for men and women. 'Throughout much of the world, women are less likely than men to have received an education or have work experience and are more likely to be involved in care work for their families that will interrupt or slow down a career. This reality is reflected in statistics on permanent residency. On the surface, employment visas appear to be allocated in a gender-neutral manner: in 2004, for example, 75,025 went to women and 80,289 went to men. ${ }^{10}$ But a closer look at these statistics reveals that women are gaining immigrant status not as employees, but as family members. A green card based on employment categories carries with it the privilege of bestowing "derivative status" on the employee's dependents. That means that an employee who gains residency under, say, the multinational executive category can also obtain green cards for his spouse and children. They, in turn, will be considered employment-based immigrants, and they will count toward the annual total of employment visas. So to determine whether the men and women who receive employment-based green cards are really coming here as employees or as family members of employees, we must look to statistics on whether they are primary or derivative beneficiaries of the employment visa category. Again using the numbers for 2004, of the 75,025 women who received employment-based green cards, only 20,125 did so as the primary beneficiary; the other 54,900 were wives or children (derivatives) of primary beneficiaries. Of the 80,289 men who received employment-based green cards, 52,417 were the primary beneficiaries, and 27,872 were derivative beneficiaries. "Men overwhelmingly predominate as primary beneficiaries in employment-based immigration.

There certainly are some women who manage to obtain green cards through their own employment - in 2004, these women represented 3.9 percent of the women who obtained green cards. But the vast majority of women cannot immigrate this way. The economic experience of women in sending countries illustrates why. Imagine, for example, a very common example: an immigrant woman who would like to apply for green card status based on her ability to be a nanny. The employment categories are designed to attract immigrants in high-demand fields that are unlikely to be saturated by American workers. The Department of Labor (DOL) lists "child

10 I chose to use the numbers from 2004 because they were the most recent statistics I could find. See "Women Immigrants and Family Immigration," Legal Momentum, available at http://www.nilc.org/ (accessed Oct. 29, 2008) (citing Kelly Jeffreys, Characteristics of Family-Sponsored Legal Permanent Residents: 2004 (Washington, DC: Office of Immigration Statistics, Department of Homeland Security, 2005).

11 Ibid. 
care worker" as an in-demand field, ${ }^{12}$ and yet, our prospective immigrant would have a very difficult time finding work as a nanny in the United States - at least legally. First, she would have to apply for a green card. To do this, she would have to find an employer to sponsor her. It is unlikely, given the nature of the job, that many employers would be willing to make a commitment to sponsor a nanny without at least meeting the person who will care for their children for an interview, but this is impossible if the immigrant is living abroad.

Even if she can find an employer to sponsor her, a child care worker will have a long wait for a green card. She is not a first-preference person of extraordinary ability, outstanding professor or researcher, or multinational executive, nor is she a secondpreference professional holding an advanced degree or person of exceptional ability in the arts, science, or business. Immigrants entering under these categories can be at work in the United States within several months of applying because there is a large enough supply of slots (40,000 for each preference annually) to meet the demand. The only conceivable category our hypothetical child care worker will qualify for is the third preference for skilled and unskilled workers. This category has 40,000 spots per year but limits unskilled workers to only 10,000 slots, and the child care worker is likely to be considered unskilled. This is partly the result of the way the United States construes the terms skilled and unskilled. Immigration law defines skilled labor as work that requires at least two years of training or postsecondary education. The DOL, in turn, makes findings about specific occupations and how much training is needed for each. Because the DOL characterizes child care as needing "very little" experience, it generally counts as unskilled labor for immigration purposes. ${ }^{13}$ Because the number of unskilled workers who would like to immigrate to the United States far exceeds the 10,000 slots available, there is a long waiting list for this category. In October 2008, for example, the Citizenship and Immigration Bureau was finally processing green card applications for unskilled workers who applied for their green cards on January $1,2003 .{ }^{14}$ By the time our hypothetical nanny gets her green card, the infant she is to care for will be in kindergarten.

The classification of child care work as unskilled rests on certain assumptions about how skills are acquired. The child care worker's skill set was not acquired during an apprenticeship or graduate school, but instead during a lifetime of caring for other family members, gender socialization, and prioritizing family tasks over more individualistic pursuits. Child care is a job that many men would be unqualified for precisely because they have not received the same training and acculturation that many women have received - because they lack certain skills. The DOL's classification of this work as unskilled means that for the millions of

12 "Summary Report for Child Care Workers," O* net, available at http://online.onetcenter.org/ (accessed Feb. 23, 2009) (listing "child care worker" as an in-demand field).

13 Ibid. (listing "child care worker" as an occupation for which "some previous work-related skill, knowledge, or experience may be helpful .. . but usually is not needed" and for which "employees need anywhere from a few months to a year of working with experienced employees").

14 See "Visa Bulletin for October 2008," available at http://travel.state.gov/ (accessed Oct. 29, 2008). 
women who count extensive child care experience as their primary employment credential, legal employment-based immigration is not an option, nor is citizenship flowing from legal employment-based immigration. Such a woman, unlike the computer programmer, biology professor, clergyman, or physical therapist, cannot say, "I acquired citizenship in part because I had an important skill that was in short supply in the United States." Her most likely option for obtaining citizenship is to do so by marrying a U.S. citizen or as a derivative spouse of a male employment-based immigrant.

\section{Becoming a Citizen Through Marriage}

\section{Why Marriage?}

In employment-based immigration, the theory behind the preferences is easy to deduce. Congress has allocated the largest numbers of slots to immigrants who have skills or experience that will be useful to the American economy, without displacing native workers. Family-based immigration is more complicated. It is not self-evident why spouses of U.S. citizens would be more likely than other immigrants to add value to the nation, both as permanent residents and, eventually, as naturalized citizens.

Surely from the perspective of immigration law, the reason to privilege marriage is largely one of administrative convenience; marriage provides a clear-cut category for determining whether a romantic relationship is significant enough to trigger permanent resident status for an immigrant. Inquiring into the details of individual relationships to determine whether a relationship is substantial and permanent would be unwieldy and potentially invasive. As in other areas of law, by allowing the state to cut through potentially enormous amounts of red tape, marriage does the work. But administrative convenience does not tell the whole story. The United States provides much broader family-based immigration than most Western receiving countries; there is nothing about marriage that necessarily gives an immigrant the right to relocate or change her citizenship. So why would the United States rely on marriage to do so much work in creating the pool of future citizens?

There are several ways of thinking about why marriage, immigration status, and citizenship might, as a normative matter, be so closely tied. First, marriage is a useful way to determine whether someone is already a partial member of a community. By demonstrating a marital relationship, a prospective immigrant or citizen is in one sense already demonstrating that she is worthy of membership in the society. She is essentially saying, "I am a member because I have close ties to a member," or even, "I am a member because a member has chosen me." Marriage makes the membership. A strong version of this theory of citizenship was evidenced in the Citizenship Act of 1855, which made any woman who married a male U.S. citizen automatically a U.S. citizen herself, and the Expatriation Act of 1907, which automatically divested any female U.S. citizen of her citizenship if she married a foreigner. Under this theory, 
a woman could not be loyal to a nation and a husband of a different nationality. The act of attaining or renouncing citizenship was simultaneous with the act of marriage. 'There was no process of "becoming a citizen;" it simply happened when marriage happened. Today, women are no longer treated differently than men as an official matter, and marriage and citizenship are not statuses that immigrants enter into simultaneously. But the privileging of marriage relationships in citizenship still represents a weak form of the view that the fact of marriage gives us evidence that some cultural assimilation has already occurred.

Second, we might think of the treatment of marriage as a prediction of assimilation and value. A person who marries a U.S. citizen might be perceived as more likely to become a stable, productive citizen. This might be because the U.S. citizen is more likely to be already embedded within American culture, in terms of friendships, employment contacts, linguistic competence, and cultural literacy. It also might be because a married couple is more likely to achieve financial stability, and this will reduce the immigrant's likelihood of becoming a public charge. In this view, the family functions as a crucible for assimilation. What exactly are the American values we expect to be inculcated through the marital relationship? These values depend in part on the kind of marriage being practiced, which may explain why immigration law does not recognize, for example, polygamous marriages. Immigration law's preferences for spousal immigration could rely on a strong presumption that the citizen spouse will exert a stronger pull, possibly because she will be constantly supported by the surrounding culture, than the immigrant spouse, thus working to acculturate the noncitizen. But in some communities, especially where the citizen spouse is a recent immigrant himself, this may not be the case at all. The more recent immigrant spouse could perform the role of preventing the citizen spouse from becoming too American by acting as a reminder of the cultural norms of the home country and thwarting assimilation.

Third, marriage and citizenship may be linked because we care about the rights of U.S. citizens to exercise their own citizenship through transmitting it to others. Citizens exercise citizenship in many ways - by voting, by participation in public and civic life, by service on juries, and by service in the military (although many of these exercises of citizenship are or have been available to noncitizens as well). One way in which citizens can exercise their citizenship is by transmitting it to someone else - to a child or to a spouse. Although courts have been reluctant to explicitly grant rights to immigrants based on the interests of their citizen relatives, sympathy for the plight of U.S. citizens stranded without their loved ones pervades the immigration statutes. Not only do the admissions categories favor family immigrants, but the waivers to exclusions based on the immigrant's health, criminal background, or fraudulent activity all focus on the question of whether excluding the immigrant will cause hardship to the U.S. citizen or permanent resident, not the immigrant. Although there is no constitutional right to family unity in this regime, Americans who seek to reunite with their foreign family members are given statutory assistance. 
Marriage, then, is linked to immigration and citizenship status in important ways, and for a variety of reasons. Some of these reasons may include the idea that marriage tells us something, both retrospectively and prospectively, about the likelihood that an immigrant will assimilate successfully, and the idea that marriage is a valuable enough activity for citizens that we should facilitate their ability to marry, even if their choice of mate is not an American. But marriage also requires the parties to the marriage to take on certain burdens, including a duty of support and a duty of services to the other. Requiring couples to be married does not simply take the temperature of the relationship to determine the legitimacy of the bond. It also measures how willing a couple is to enter into an institution with a lot of moral and political baggage and to take on obligations of financial support to each other. And because marriage operates as a near prerequisite to citizenship for many women, it is worth thinking about how marriage shapes women's identity and what the costs of relying on it to create a pool of citizens might be.

\section{How Immigration Law Shapes Marriage}

A first-order issue is the conditions under which women marry in their countries of origin. Despite divorce reforms, including the move to a no-fault divorce system that took place in the United States and many Western democracies in the 1970s, many countries still retain divorce laws in which it is difficult or impossible for a woman to extricate herself from a bad marriage. In many countries, the average age of marriage for women is very young, and because women have scarce opportunities to enter into professions or trades that would make them self-supporting, marriage is the only economically viable option, even if the terms of marriage are not optimal.

Once they arrive in the United States, immigration law encourages immigrants to shape their marriages in ways that conform to an American model of marriage. To demonstrate that a newly entered marriage is not fraudulent, immigrants (and their citizen spouses) must provide evidence of the legitimacy of their marriages. This evidence usually goes far beyond documentation that the marriage occurred; the regulations, for example, list the following as factors to be considered: (1) documentation showing joint ownership of property; (2) a lease showing joint tenancy of a common residence; (3) documentation showing commingling of financial resources; (4) birth certificates of children born to the marriage; (5) affidavits of third parties having knowledge of the bona fides of the marital relationship; or (6) other documentation establishing that the marriage was not entered into to evade the immigration laws of the United States. ${ }^{15}$ In other words, the immigrant is encouraged, although not required, to shape her identity in ways that will make her marriage look bona fide, and these ways basically boil down to cohabitation, commingling of funds, and children, regardless of what marriage means to her and her spouse. It is the 
interdependency of marriage, and its sexual and reproductive aspects, that are seen as indicia of genuineness. Although the regulations do not say it, it is highly unlikely that a married couple who admitted they had no romantic or sexual relationship would qualify as bona fide for immigration purposes. Participation in heterosexual marriage, and a very particular kind at that, is the prerequisite for permanent resident status based on a personal relationship. This requirement can shape marriages in various directions. Some couples may make their marriages more traditional in an effort to demonstrate their bona fides. But for some couples, the requirements may force them to make their marriages more egalitarian. A joint bank account, for example, might be a step back from separate bank accounts but an improvement from one bank account, accessible only by the husband.

The act of becoming a citizen through heterosexual marriage carries with it the corollary that one cannot become a citizen through other relationships. Under the Defense of Marriage Act, a "spouse" is defined as an opposite-sex marital partner, and "marriage" is defined as a union between a man and a woman. Therefore, every time an immigration law provision refers to "spouse" or "marriage," it means only opposite-sex spouses and marriages, regardless of whether a couple has been legally married under the law of another country. ${ }^{16}$

Much has been written on the effect that this exclusion has on gay and lesbian couples seeking immigration status. ${ }^{17}$ In many cases, it means that couples are unable to live together because there is no alternative immigration category available. Some couples have resorted to marriage fraud (in which the immigrant spouse marries a U.S. citizen of the opposite sex) to live in the same place. The nonrecognition of same-sex relationships may affect the development of these relationships. In nascent relationships in which two people know they have little chance of being able eventually to live together, investing in a long-term relationship may simply seem out of the question. Denying gay and lesbian citizens the opportunity to sponsor a spouse puts them in a different relationship to the state than other citizens. Their citizenship rights are reduced; this particular aspect of their citizenship can be exercised only by entering into a marriage that feels like a sham. Because marriage is the institution that assimilates the noncitizen spouse to American values and culture, the law's refusal to recognize same-sex marriages implies that there is something unAmerican about these marriages. Assuming that the noncitizen spouse plans to reside in a state that recognizes same-sex marriage or domestic partnerships, which seems fairly likely, it is unclear what makes him or her so different from the American citizens already living there. (If anything, a person who immigrates to the United States might be doing so because a gay or lesbian identity is more accepted in American culture than in her country of origin.)

16 Adams v. Howerton, 673 F.2d 1036, 1038 (9th Cir. 1982); 1 U.S.C. S 7 (2000).

17 In addition, much has been written about the history of the categorical exclusion of gays and lesbians as immigrants, regardless of their relationship status. See, e.g., William N. Eskridge Jr. and Nan D. Hunter, eds., Sexuality, Gender, and the Law (New York: Foundation Press, 2004), at 1360-67. 
In addition to encouraging immigrants to shape their marriages into a particular brand of heterosexual union to avoid the appearance of fraud, immigration law also shapes immigrant marriages in other ways. The first of these is the somewhat curious practice of requiring the citizen or legal resident spouse to "sponsor" the immigrant spouse for immigration status, rather than simply having the immigrant apply herself. Under the Immigration and Nationality Act, an immigrant who wants to use his or her status as a spouse of a U.S. citizen or permanent resident does not automatically become eligible to file for a green card. Instead, the immigrant's citizen spouse must sponsor her for green card status. In other words, a citizen can prevent his spouse, whether intentionally or negligently, from obtaining legal status simply by failing to file the appropriate paperwork, and there is nothing the immigrant spouse can do about it.

In the context of current family law, the spousal sponsorship requirement looks quite unusual. Marriage in family law is a hybrid institution that is part status and part contract, and there are some core status concepts that exist to prevent one spouse from taking unfair advantage of the other. For example, many states have elective share laws that ensure that a surviving spouse will receive a fair portion of a deceased spouse's estate, even if the deceased spouse explicitly disinherited the surviving spouse in her will. Furthermore, courts frequently refuse to enforce contracts between married couples if the contract would work a financial injustice on one party, and they certainly do not allow one spouse to dictate to the other whether to work outside the home, where to live, or whether to travel. In one sense, the whole point of marriage is to access a set of benefits and burdens: each spouse gains rights vis-à-vis the other, and those rights create reciprocal burdens - the right to be supported also means a duty to support.

Immigration law turns the idea of marriage as a committed status into an institution into which a citizen spouse can selectively opt in or out. If citizen spouses want their immigrant spouses to come to the United States to live with them, they can choose to sponsor them, but if they would rather keep them at a distance, they have the option of refusing to do so. Immigration law essentially gives the reins to the citizen spouse to decide what his or her marriage means, regardless of the wishes of the immigrant spouse.

Although the spousal sponsorship requirement strikes an odd chord in the context of marriage law today, when it was first instituted, it made much more sense. At common law, a woman's citizenship followed her husband's, and husbands, as heads of household, had decision-making control over many aspects of their wives' lives, including whether to administer chastisement, how to manage the wife's property, and where the couple would live. Although domestic relations law had changed considerably by the 1920 , when the first numerical quotas were placed on immigration, the idea of the husband as head of household was still reflected in the laws. Unlike today's immigration law, which defines an "immediate relative" as the spouse or child of a citizen, the 1921 Immigration Act defined an immediate relative as the wife of a male citizen. Husbands of female citizens were not eligible to 
immigrate based on their marriages; in fact, their citizen wives lost U.S. citizenship by marrying a foreigner. ${ }^{18}$ Control over a wife's immigration status was seen as part and parcel of a husband's right to control his household; wives did not share the same right. When a visa requirement was added in 1924, it made sense that a wife claiming to be entitled to a visa by virtue of her marriage to a U.S. citizen husband would need, in essence, to seek her husband's permission to do so by asking him to file a petition on her behalf. ${ }^{19}$ The male head of houschold was the decision maker regarding the domicile not only of his children, but of his wife. ${ }^{20}$

This formal discrimination between husbands and wives was eliminated in 1952, when Congress changed the word "wife" to "spouse" and gave both male and female citizen spouses control over their immigrant spouses' immigration status. ${ }^{21}$ But making the statute gender-neutral has not resulted in substantive equality. Because a majority of immigrants who use their status as the spouse of a U.S. citizen to obtain legal immigration status are female, the law disproportionately affects immigrant women. The law continues to grant astonishing power to the citizen spouse. People often do things their spouses do not like - they spend too much of the couple's joint income; they work outside the home (or do not); they have different standards of cleanliness, or television watching, or parenting - but the law does not usually interfere to give one spouse power over the other's decision-making process. In marriages in which wives already experience subordination, the additional power to the husband conferred by immigration law can exacerbate these power dynamics.

Contemporary immigration law's retention of the spousal sponsorship requirement may once again rest on concerns about administrative convenience: this is the way things had been done before, and the spousal sponsorship requirement neatly matches the requirement that an employer sponsor an immigrant in the employment categories. There may also be concerns about fraud: what if the immigrant spouse is lying about the marital relationship? Although this should be easy to detect through documentation, requiring the citizen spouse (who, in theory, might have less of an interest than the immigrant in the immigrant's permanent residency if the marriage were a sham) to sponsor the immigrant might reduce the number of fraud cases. Convenience aside, however, the spousal sponsorship requirement has serious consequences for immigrant spouses. As an expressive matter, the citizen spouse stands in for the nation. The immigrant spouse's reason for obtaining legal permanent residency (and, ultimately, citizenship) is her tie to the citizen spouse. A marriage on paper may not be enough to ensure that the tie is significant enough to

\footnotetext{
18 Act of May 29, 1921, Pub. L. 5, \$2(a), 42 Stat. 5; Expatriation Act, ch. 2534, S 3, 34 Stat. 1228, $1228-29$ (1907).

19 Act of May 26, 1924, ch. 190, S 7(b), 43 Stat. 153, 156 (1952).

20 Indeed, a wife's domicile was presumed to follow that of her husband for jurisdictional purposes well into the twentieth century. See Mas v. Perry, 489 F.2d 1396 (5th Cir. 1974) (overturning a lower court decision that a U.S. citizen wife's domicile followed that of her foreign husband).

21 An Act to Revise the Laws Relating to Immigration, Naturalization, and Nationality; and for Other Purposes, Pub. L. 82-414, 66 Stat. 163, 178 (1952).
} 
warrant lawful permanent resident status; the emergence of no-fault divorce means that marriage as a legal status has ceased to have permanence. The nation relies on the citizen spouse to make this judgment call, based on his feelings about the immigrant spouse. Is the couple really in it for the long haul? If so, then the nation is, too.

The spousal sponsorship requirement also has the potential to alter the dynamics of a marriage in unintended ways. It gives the citizen spouse power that one spouse does not normally have over the other, at least not in the United States. Indeed, the spousal sponsorship requirement was a major cause of the passage of the immigration portions of the Violence Against Women Act (VAWA), which create exceptions to the spousal sponsorship rules for battered spouses. Because citizen spouses sometimes use the threat of nonsponsorship to keep an immigrant spouse in an otherwise abusive relationship, VAWA created exceptions for immigrant spouses who could prove they were battered. But the necessity of VAWA should make us wonder about the sponsorship requirement altogether: why should one member of a married couple be allowed to dictate what marriage means for immigration and, ultimately, citizenship? The act of sponsorship becomes a symbolic act of charity, altruism, and sacrifice on the part of the citizen spouse, in part because it is not required. The immigrant spouse comes to the United States already indebted to the citizen spouse: she eventually becomes eligible for naturalization because of the good graces of an American who was kind enough to sponsor her. For the citizen spouse, the act of sponsorship is an exercise of citizenship: through sponsorship, he transmits his citizenship to another, and this act is independent of the decision to marry. Control goes to the citizen spouse in part because of the notion that citizen spouses have rights to be with their families if they want to be. It is a right not of marriage, but of citizenship.

Immigration law not only puts the immigrant spouse in a subordinated position, but it also forces the sponsoring, citizen spouse into a breadwinning position. In addition to sponsoring his immigrant spouse, the citizen spouse must also sign an affidavit of support that demonstrates that he can support the immigrant at an annual income that is not less than 125 percent of the federal poverty line. This number is calculated by adding the immigrant (and any relatives immigrating with her) to the number of people already in the sponsor's household and looking up the federally published salary necessary for that year. The immigrant spouse's ability to earn an income herself will be deemed irrelevant in the calculation. The obligation of support is potentially permanent; it ends only if the sponsored immigrant becomes a naturalized citizen; she works for approximately ten years (or, in the case of a married immigrant, her spouse works for ten years while they are married); she relinquishes permanent resident status and leaves the country; or she dies. None of these exigencies is completely within the control of the citizen sponsor. If the immigrant spouse chooses not to apply for citizenship or refuses or cannot work, she can sue her citizen sponsor for support under the affidavit of support, even if they have divorced. The affidavit of support requirement forces the citizen spouse 
into a breadwinning role regardless of the actual dynamics of the relationship, and has the potential to do so even once the marriage is over. ${ }^{22}$

Together, the requirement that marriage be heterosexual, the grant of control to the citizen spouse over the immigrant spouse's immigration status, the requirement that the citizen spouse demonstrate that he can function as a breadwinner, and the strong incentives couples are given to conform to particular ideals of cohabitation, commingling of funds, and children add up to a vision of a particular kind of heterosexual marriage in which one family member subordinates her autonomy and identity to her spouse. Of course, the law is completely gender-neutral. There is no requirement that the citizen spouse be a man, or that the immigrant spouse be a woman. A woman citizen will have to demonstrate breadwinning capabilities and will have decision-making authority over whether her husband can apply for a green card. But given the gendered dynamics that already exist in many marriages, and given that the majority of marriage-based immigration involves citizen husbands sponsoring immigrant wives, the implications of the law for many citizen-immigrant marriages are troubling. By demanding that immigrants fit a traditional model of marital gender roles, the law may be perpetuating and exacerbating these roles in ways that are harmful to women.

\section{Naturalization}

Immigration law, then, shapes the pool of potential naturalized citizens and puts them through a crucible of training to become Americans by their participation in heterosexual marriage. But once a green card is acquired, this process goes on. The default rule for citizenship is that the applicant must undergo a five-year residency period after obtaining a green card. But for spouses of citizens, regardless of the immigrant category used for green card purposes, this period is reduced to three years if they are "living in marital union." Unlike in the context of immigration law, there is no administrative convenience purpose for this rule. There, the law is trying in part to ascertain whether a relationship really counts as a family relationship, but here, all green card holders are eligible to naturalize if they meet the residency requirements, take the oath, pass the tests, and are of "good moral character." In the case of the reduced number of years for citizenship, we see a more concentrated example of what we saw in the immigration context: marriage to a citizen is a proxy for

228 U.S.C. S 1183 a (2002); 8 C.F.R. \& 213a.2(e) (2007); Form I-864P. The sponsor's obligation to support the immigrant also terminates if the sponsor dies. 8 C.F.R.

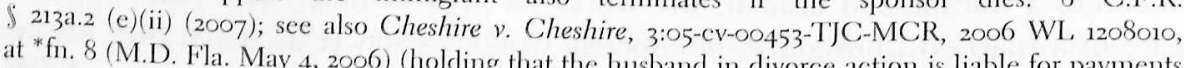
at *fn. 8 (M.D. Fla. May 4, 2006) (holding that the husband in divorce action is liable for payments based on affidavit of support, that it is immaterial whether the defendant can afford the judgment, terminates if the sponsor dies. 8 C.F.R. . 213a.2 (e)(ii) (2007). However, if the deceased sponsor failed to support the immigrant while alive, the immigrant may sue the deceased's estate. 8 C.F.R. $\int 213$ a.2 (e)(2) (termination does not relieve the sponsor's estate from any reimbursement obligation that accrued before termination). 
assimilation, both prospectively and retrospectively, and the reduced waiting period can also be construed as a privilege of citizenship enjoyed by the citizen spouse. Once again, engagement in heterosexual marriage is thought to shape immigrants in a way that makes them more likely to be true "Americans" by the time they naturalize. Also, once again, same-sex marriages do not qualify. From the government's perspective, perhaps a married legal resident is less risky than a single resident or someone married to a foreigner. The government is willing to make the jump from granting legal residency (which can be revoked if the immigrant commits a crime, or spends too much time living abroad, or demonstrates bad moral character) to granting citizenship (which is permanent) at an earlier date than it would for someone else. Marriage tames the immigrant into a citizen.

\section{Becoming a Citizen by Becoming a Victim}

By privileging family immigration and granting citizens the power to withhold sponsorship from their immigrant spouses, U.S. immigration law has created a need for a patchwork of exceptions to the normal rules of immigration admissions. Whereas normally, an immigrant must demonstrate family ties, employment opportunities, or refugee status or win the diversity lottery to gain legal admission, the law makes exceptions for battered spouses and children. It does so in part because of the perverse effect of the spousal sponsorship requirement: some spouses withhold or threaten to withhold sponsorship to keep their spouses in an abusive relationship. The law provides a self-petitioning option for immigrants who demonstrate that they have been battered or subjected to "extreme cruelty" by their citizen or permanent resident spouses. In these cases, because of the immigrant's status as a battered spouse, the citizen spouse loses control over the immigration process. ${ }^{23}$

In addition to qualifying for exceptions to the general immigration rules, battered spouses are also eligible for exceptions to the general naturalization rules. Battered spouses are entitled to naturalize in three years, just as if they were married to a U.S. citizen, even if they have divorced the citizen. If a person obtained lawful permanent resident status "by reason of his or her status as a spouse or child of a United States citizen who battered him or her or subjected him or her to extreme cruelty," then the person is still entitled to the three-year, instead of the normal five-year, waiting period. ${ }^{24}$

All of these provisions became law as part of the VAWA of 1994 and subsequent VAWA amendments. As the title of the act suggests, Congress was concerned about the plight of battered women, not battered men, when it passed VAWA. The immigration provisions, like most immigration provisions today, are gender-neutral on their face. But they are designed to treat a problem that Congress believed affected mostly women, and indeed, women are far more likely to bring VAWA claims than

248 U.S.C. $\int 1430(\mathrm{a})(2008)$. 
men and to have those claims taken seriously when they do. 'The law thus affects men and women very differently, both in terms of who is likely to take advantage of it and in terms of how it shapes the identities of those who do.

The VAWA exceptions provide a challenge to the usual idea that citizenship involves a consenting relationship between citizen and state. In the case of a battered spouse, the reason for her relationship with the state - both in the initial inquiry concerning her green card status and later, during the naturalization process - is her battering. She thus consents to a relationship with a nation because of her involvement in a relationship that violated her consent. We might even think that she is not in a position to consent because she is fleeing a relationship of coercion. These exceptions also twist the usual way in which marriage is used as a shortcut to citizenship status. In the usual case, the law presumes that marriage helps to assimilate the immigrant; through the relationship with the citizen spouse, the immigrant becomes more likely to be a productive citizen. In the battering cases, the state steps in to replace the battering spouse. The new citizen's treatment by her spouse in a private space becomes the basis for her public relationship with the nation. But instead of the private relationship standing in for the project of assimilation, public belonging is now the result of the deviance and corruption of the private relationship; the prospective citizen's relationship with the nation is a substitute for her relationship with a husband/protector who has gone wrong. The nation must step in as her protector.

From the government's perspective, a green card given because of an immigrant's victim status looks very different from one given based on an immigrant's employment potential or family connections. In the latter cases, the decision to make residency legal - and ultimately, to open the possibility of citizenship - appears to be based on a calculation that the immigrant is likely to be of value to the country, either because of the skills she brings as a worker or the stability she offers as a family member of a citizen or resident. As we have seen, in the case of the family preferences, there is also a sense that she is more assimilable because of her family relationship. In the case of the battered immigrant, it is unclear what exactly the nation gains by giving the immigrant a green card. Battered spouses do not appear to have superior character traits or skills (at least not any that result from their being battered), and if the family relationship that produced the visa application has ended, it is unclear why the government would think that the immigrant would provide stability to the citizen's family life. If anything, a truly merit-based immigration system might worry that admitting victims of domestic violence would undermine the principles of immigration law; even if it is not the immigrant's fault, being a victim is not usually a qualification for a green card or citizenship, just as being poor or unskilled is not. In the case of domestic violence victims, the nation appears to be offering a helping hand not because the immigrant brings something special to the nation, but because the nation placed the immigrant at risk. It is the nation's fault, in a sense, that it required the victim to be sponsored by her spouse, so if the nation wants to justify keeping the spousal sponsorship requirement in most cases, it must 
make exceptions for the cases in which the citizen spouse has not upheld his end of the bargain.

The VAWA petitioner who ultimately becomes a citizen, then, stands in marked contrast to the family-or employer-sponsored immigrant. The immediate relative is worthy because of a flourishing relationship (even if we might worry that flourishing marital relationships can nevertheless be subordinating); the employee is worthy because she can do work that is needed in this country, for which American workers are not available. But the battered spouse petitioner gains green card status not because she is a desirable worker or family member, but because the state has stepped in to protect her. To become a citizen, a VAWA immigrant must first become a victim.

\section{Conclusion}

This chapter has shown that citizenship does not occur at the moment of naturalization, but is instead a process, occurring over several years. The law explicitly imposes this process by specifying the categories of immigrants who may ultimately apply for naturalization. These immigrants become citizens not primarily through studying for their naturalization exams or learning English, although these are important elements, but through the everyday actions of living their lives. The United States puts particular stock in the ability of citizens to acculturate their immigrant spouses through marriage. Encouraging immigration based on marriage, then, is both a reflection of this reality and a way of reifying it.

The emphasis on family-based immigration and the limitation on access to employment-based immigration have a profound influence on the way in which women become citizens. For many women, the process of becoming occurs through participation in heterosexual marriage, an institution that shapes identity in ways that are sometimes subordinating for women. As Nancy Cott has shown, the institution of marriage has been "the vehicle for the state's part in forming and sustaining the gender order," and the law of immigration and citizenship has, throughout history, aided and abetted this formation and sustenance. ${ }^{25}$ In the case of immigration law, the law deepens marriage's subordinating potential by putting immigrant spouses at the mercy of their citizen sponsors, who can refuse to offer sponsorship; even a woman who does not experience heterosexual marriage as subordinating has the dynamics of her marriage altered through the requirement that she seek her husband's approval to apply for permanent resident status and by the requirement that he demonstrate his financial ability to support her regardless of her own earning potential. For those women whose marriages fail due to violence and abuse, the system offers an unfortunate resolution: they may become citizens capable of choosing allegiance to the

25 Nancy F. Cott, “Marriage and Women's Citizenship in the United States, 1830-1934," 103 Am. Hist. Rev. 1140, 1442 (1998). 
United States, but only by demonstrating that they have experienced a failure of autonomy in their personal lives.

In addition to telling us much about what the United States values in assessing potential citizens, immigration law also tells us something important about how the United States allows its citizens to exercise their citizenship. Citizens can sponsor their spouses, and indeed are given control over the decision of whether an immigrant spouse will live in the United States. For some citizens (who are likely to be disproportionately male), this ability may often mean not only access to companionship and friendship, but also access to someone to care for children and to perform household labor. But for citizens who wish to sponsor an employee, rather than a relative, to perform care work, immigration law fails to provide a legal means. Because of the gendered allocation of household labor that persists in the majority of American families, immigration law's privileging of the family member over the care worker affects the ability of U.S. citizens to exercise their citizenship by extending immigration status to others in ways that are also gendered. Men are simply more likely to be able to depend on a wife to perform care work for free than women are able to depend on men; most women must go to the open market if they seek assistance in this work, and immigration law does not allow them to do so legally. Just a few decades ago, immigration patterns commonly involved early migration by men, followed by family migration of their wives and children. That pattern is now changing: many women are migrating, including women with families, alone, commonly to do care work for other people's families. ${ }^{26}$ Although there are reasons to be very concerned about commodification of care work and exploitation of domestic workers, pushing these practices underground and refusing to recognize the citizenship potential of women involved in this work does nothing to ameliorate these concerns.

Of course, not all immigrants who obtain legal residency, and ultimately, citizenship, through employment are men, and not all those who obtain it through family relationships or victim status are women. For some couples, the system may even have subversive potential. A system that demands that the U.S. citizen spouse take on the role of decision maker, sponsor, and breadwinner may not only entrench the subordination in some marriages, but also may provide the possibility of role reversal in others. Given the ways in which many marriages retain at least some vestiges of traditional gender roles, however, it seems likely that much of the effect of the law is a one-way ratchet. Even an ostensibly gender-neutral requirement like the spousal sponsorship requirement, or the exceptions for battered spouses - male and female set forth in VAWA, may have, on average, very different influences on men and women because of their different experiences of marriage as an institution.

Every naturalized citizen has an immigration story and a citizenship story. This chapter has tried to show that these stories are related, perhaps even coextensive. The

${ }^{26}$ See, e.g., Rhacel Salazar Parrenas, "The Care Crisis in the Philippines: Children and Transnational Families in the New Global Economy," in Barbara Ehrenreich and Arlie Russell Hoschschild, eds., Global Women: Nannies, Maids, and Sex Workers in the New Economy (New York: Metropolitan Books, 2002), at 39-54. 
story of naturalization is not simply a story of jumping through the hoops required by the naturalization laws; it is also one of establishing a legal identity as an immigrant by qualifying for a particular type of immigration status, and then living in the United States for a period of time, most often engaging every day in the activity, be it marriage or employment, that justified the status in the first place. Thus, a person's immigration story informs her citizenship story.

The woman whose immigration story is one of following her husband because of his job prospects is in a different position vis-à-vis the nation on the eve of her naturalization ceremony than is the immigrant computer programmer who obtained an employment-based green card, or the refugee who suffered political persecution, or even the diversity lottery winner who was simply lucky. Her contribution to the United States is qualitatively different, based not on the value of her skills, a moral claim of entitlement because of persecution, or growing up in an underrepresented country, but instead on her participation as a wife in heterosexual marriage. In cases of spouses who obtain legal status because of domestic violence, the contribution is even more attenuated. The archetypical story of the fresh, entrepreneurial spirit contributed by the immigrant, of the constant reenergizing of the population through the assimilation of new blood, takes on a different cast in the case of family immigration, one where the new voices are telling an old story of marital duty and self-denial in the face of a spouse's life projects. On the eve of their naturalization, immigrants who achieve legal status as a result of family relationships or victim status have a relationship with the nation, but it is a relationship that has been mediated by their spouses. This mediated relationship between individual and nation is one that develops over time and in a process of becoming, rather than in a moment of consent between individual and nation. For some women, "becoming a woman," as defined by Beauvoir, and becoming a citizen are intertwined processes: both occur through the crucible of marriage, and learning how to be a woman in marriage is part of learning to be a citizen.

There are no easy solutions to the dilemmas outlined in this chapter. Eradicating immigration law of its privileging of the family would create serious problems, especially for children. Much of the gender difference in immigration law results from the conditions in immigrants' countries of origins and not because of the law itself. But some of the particularly troubling aspects could at least be tempered. Recognizing care work as skilled labor, for example, would give child care workers a path to citizenship because of the skills they possess. Eliminating the spousal sponsorship requirement would give immigrants the autonomy to decide for themselves whether their residency and domicile should follow that of their U.S. citizen spouses. Eliminating the affidavit of support, or altering it to reflect total family income instead of the income of the citizen spouse, would avoid reinscribing a breadwinner-dependent dynamic in marriages. Recognizing the changing gender dynamics in immigration law is an important first step to gaining substantive equality in the acquisition of citizenship. 